\title{
28 Research Square \\ GIS-based Multicriteria Decision Analysis for Settlement Areas: A Case Study in Canik
}

Cem Kilicoglu ( $\square$ cem.kilicoglu@samsun.edu.tr)

Samsun University: Samsun Universitesi https://orcid.org/0000-0003-1905-9486

\section{Research Article}

Keywords: Canik, settlement area selection, landslide, flood, biocomfort

Posted Date: September 8th, 2021

DOl: https://doi.org/10.21203/rs.3.rs-645592/v1

License: (a) (i) This work is licensed under a Creative Commons Attribution 4.0 International License. Read Full License

Version of Record: A version of this preprint was published at Environmental Science and Pollution Research on January 21st, 2022. See the published version at https://doi.org/10.1007/s11356-02117970-w. 


\section{Abstract}

In addition to population growth throughout the world due to migration from rural to urban areas, population density is constantly increasing in certain regions, thereby necessitating the introduction of new settlements in these regions. However, in the selection of settlement areas, no sufficient preliminary examinations are conducted; consequently, various natural disasters may cause significant life and property losses. Herein, the most suitable settlement areas were determined using multicriteria decision analysis in Canik District, where the population is constantly increasing. Therefore, this study is aimed to incorporate a new perspective to the studies on this subject. Within the scope of the study, landslide and flood risks, which are among the most important natural disasters in the region, were primarily evaluated, and risky areas were determined. Thereafter, suitable and unsuitable areas in terms of biocomfort, which affect people's health, peace, comfort, and psychology, and which are also significant in terms of energy efficiency, were determined. At the last stage of the study, the most suitable settlement areas that are suitable in terms of both biocomfort and low level of landslide and flood risks were determined; the calculated proportion of such areas to the total study area is only $2.1 \%$. Therefore, because these areas are insufficient for the establishment of new settlements, areas with low landslide and flood risks but unsuitable for biocomfort were secondarily determined; the ratio of these areas was calculated as $56.8 \%$. The remaining areas are inconvenient for the establishment of settlements owing to the risk of landslides and floods; the ratio of these areas was calculated as $41.1 \%$. The study is exemplary in the respect that the priority for the selection of settlement areas is specified, which can be applied for selecting new settlements for each region considering different criteria.

\section{Introduction}

The industrial revolution that occurred in the last century brought along many problems around the world. The industrial revolution, mechanization, modernization in agriculture, and changes and diversification in industry and service sectors have reduced the need for labor in agricultural areas whereas have increased the opportunities in urban centers. This process has caused migration from rural to urban areas, and population density has started to increase rapidly in centers where job opportunities are high (Sevik et al. 2020; Turkyilmaz et al. 2020; Cetin et al. 2020).

In addition to population growth worldwide, migration from rural to urban areas has led to congestion in urban areas. The total world population in the 1900s was only approximately 700 million, and approximately $9 \%$ of the population lived in urban areas; conversely, the world population exceeded 7.8 billion in 2020 , and the proportion of the population living in urban areas increased to $56 \%$. It is estimated that the world population will exceed 8.5 billion by 2030 , and the proportion of the population living in urban areas may reach $90 \%$. In Turkey, the proportion of the population living in urban areas has reached 92.5\% (Şen et al. 2018; Aricak et al. 2020; Worldometer 2020; Şevik 2020; TUIK 2020).

The concentration of population in urban areas has reached such a serious level in the 21st century, the world faces two major irreversible and inevitable problems, i.e. climate change caused by human 
activities and unrestricted urban sprawl (Moradi et al. 2017; Ozel et al. 2021; Varol et al. 2021). Moreover, planning deficiencies in urban areas cause many problems such as infrastructure problems, unhealthy living conditions, high traffic density, and environmental pollution (Aricak et al. 2019; Kilicoglu et al. 2020; Cesur et al. 2020). One of the most significant problems caused by unplanned urbanization is the loss of life and property as a result of various disasters. Natural disasters are the biggest threat to the need for a safe shelter. A disaster is a situation that disrupts, interrupts, or stops the normal functioning of natural and cultural resources as well as people. Despite the current development, disasters can cost hundreds of lives and billions of USD in financial losses every year (Kilicoglu et al. 2021).

Planned urbanization is one of the most effective methods against natural disasters. With preliminary studies to be conducted, performing risk analyses in each region for establishing settlement units in the most risk-free areas in terms of natural disasters will prevent the loss of lives and property in the event of a disaster. This study has attempted to identify criteria that can be considered for determining the most suitable areas to be introduced as new settlements in the Canik District of Samsun Province, where population has started to increase significantly in recent years. Within the scope of the study, risky areas in terms of floods and landslides, the most important disasters in the region, were primarily determined. Thereafter, suitable areas were determined in terms of biocomfort, which directly affects human comfort and well-being and is also highly effective on energy consumption. Consequently, the most suitable potential settlement areas depending on these parameters were aimed to be determined.

\section{Material And Method \\ 2.1. Study area}

This study was conducted on the scale of Canik District, which is one of the most important districts in Samsun and one of the biggest cities in Turkey. Canik is very attractive owing to its location and social opportunities. The population is constantly increasing owing to its highly favorable climate conditions. Therefore, introducing new settlement areas in this district is imperative. The geographical location of Canik District, which was chosen as the study area owing to the abovementioned factors, is given in Fig. 1. According to the Address Based Population Registration System, the population of Canik was 101,253 in 2020 and the annual growth rate of population is $21 \%$. The district is between $41^{\circ} 4^{\prime} 4.5^{\prime \prime}-41^{\circ}$ $16^{\prime} 44.6^{\prime \prime}$ north latitude and $36^{\circ} 12^{\prime} 2.89^{\prime \prime}-36^{\circ} 24^{\prime} 13.35^{\prime \prime}$ east longitude and has an area of $262 \mathrm{~km}^{2}$.

\subsection{Method}

Within the scope of the study, the landslide susceptibility maps of the study area, followed by flood susceptibility and biocomfort suitability maps were created. In the last stage, areas suitable and unsuitable as settlement in terms of landslides and floods were determined. Moreover, these areas were combined with the biocomfort maps, and the final settlement area suitability map was created.

\subsubsection{Creation of landslide susceptibility maps}


In this study, the 1:100,000 scale geological and 1:25,000 scale landslide inventory maps obtained from the General Directorate of Mineral Research and Exploration and 1:25,000 scale topographic maps obtained from the General Directorate of Mapping were used. A 10-m resolution digital elevation model (DEM) of the study area was produced in the ArcGIS 10.5 software using contour lines on digital topographic maps. Thematic maps of the factors used in the creation of the landslide susceptibility maps were derived from this DEM. The model that was used to produce the landslide susceptibility maps was processed in the R 3.6 .3 software.

\section{Landslide inventory, geology, landslide-conditioning factors, preparation of training and validation datasets}

Landslide inventory maps are the basic data for landslide susceptibility analysis. A landslide inventory map is a systematic map that contains information about the spatial distribution and type of landslides. To predict the landslides that may occur in the future, first, the basic features of the landslide areas shown in the inventory map should be determined (Erener and Düzgün 2016). Three basic methods named as statistics, software (soft computing), and the combination of index maps (Akgun et al. 2012) are used to produce medium-sized landslide susceptibility maps using GIS. In the present study, 1/25,000 scaled landslide inventory map produced by General Directorate of Mining Research and Exploration (GDMRE) in 2007 was used. With regards to their activities, 13 of the total 20 landslide polygons shown in the landslide susceptibility map are considered as old landslides and 7 of them are considered as active landslides.

Figure 2 shows eight different lithological units in the study area. The oldest unit in the field is the Upper Cretaceous Cankurtaran Formation (Kc); it comprises the alternation of sandstone, marl, and shale. The Upper Cretaceous-Paleocene Akveren Formation (Kta); it includes limestone, sandy limestone, marl, sandstone, siltstone, claystone, mudstone tuff, tuffite, and dacite units. Atbaşı formation (Tpea), which is the unit comprising sandstone, shale, marl, and mudstones, is aged as the Upper Paleocene-Lower Eocene.

The Middle Eocene aged Kusuri formation (Tek) comprises marl, sandstone, siltstone, limestone, and calcareous sandstone. Moreover, Middle Eocene aged Tekkeköy formation (Tet) is observed in the field with basalt, andesite, tuff, agglomerate, tuffite, sandstone, marl, and siltstone interbedded levels. Upper Miocene-Pliocene aged Mahmurdağ Volcanites (Tmplm) were observed in the study area as basalt, andesite, agglomerate, and tuff, as well as dykes and sills. Two Quaternary units exist in the study area: Qal, with clay, silt, sand, and gravel; Qt represents the current flood plain (Keskin 2011; Akinci et al. 2017).

Nine different parameters were used in the study: elevation, slope, aspect, TWI, curvature, lithology, distance from drainage network $(\mathrm{m})$, distance from roads $(\mathrm{m})$. The factor maps prepared in ESRI ArcGIS 10.5 were converted to raster format with a spatial resolution of $10 \mathrm{~m}$. Factor maps are presented in Figs. 3 and 4. 


\section{Landslide susceptibility assessment using a random forest (RF) model}

Breiman (2001) was the first to develop the classification and use of several decision tree models simultaneously in regression problem solving and apply them to collective learning algorithms. RF methods have been frequently used in GIS-based landslide susceptibility mapping studies (Youssef el. al. 2016; Taalab et. al. 2018; Kim et. al. 2018; Hong et. al. 2019; Nhu et. al. 2020).

To apply the RF model in this study, in ESRI ArcGIS 10.5 software, all factor maps used in the study were converted to raster format with a cell size of $10 \mathrm{~m} \times 10 \mathrm{~m}$. For the training and validation of the model, "landslide (or positive)" and "landslide-free (or negative)" samples were created. In the study area, the same numbers of "landslide" and "landslide-free" samples were randomly selected. Positive samples were given a value of " 1 " and negative samples of " 0 " (Akinci et. al. 2020). Seventy percent of this dataset was used for training the model, and the remaining $30 \%$ was used for the validation of the model. The RF model was implemented in the R 3.6.3 software using the caret package (Kuhn 2008).

\subsubsection{Creation of flood susceptibility maps}

Climate change, which has an impact all over the world, has increased flood risks, and especially in the last decade, this increase has revealed the necessity for urban flood risk analysis. The rapid increase in irregular urbanization has negatively affected social life and caused loss of economy and lives (Lee et al. 2012; Yin et.al. 2015; Rahmati et. al. 2016; Gigović, et. al. 2017). In recent years, flood susceptibility maps have been produced using various GIS-based methods (Bapalu et. al. 2008; Samanta et. 2018; Wang et al. 2019b; Souissi et. al. 2020). Floods are not only destructive, they also trigger landslides. Therefore, appropriate site selection and planning is necessary by producing combined hazard susceptibility analyses using multihazard susceptibility assessment and GIS (Skilodimou et. al. 2019; Yanar et. al. 2020).

In the study area, on July 04, 2012, 12 people lost their lives due to the overflowing waters from Yılanlı Creek, a branch of the Mert River; moreover, as a result of İncirli Creek overflow, the shopping center built on the creek was flooded. In this study, flood susceptibility maps were obtained from a 1/25,000 scaled standard topographic map. Stream and contour lines on the topographic map were digitized using the ArcGIS 10.5 software, and primarily, a DEM of the study area was produced. After the DEM was converted to the ESRI GRID format, the elevation aspect and topographic humidity index maps of the study area were produced. Thereafter, maps were produced based on a $250-\mathrm{m}$ buffer zone for the stream digitized from the $1 / 25,000$ scaled standard topographic map.

While determining the limit weight values of the regions in the susceptibility model, a natural breaks classification method was used. The study area was divided into five classes as "very low (1), low (2), medium (3), high (4), and very high (5)."

\subsubsection{Creation of biocomfort suitability maps}


To create biocomfort maps, long-term climate parameters were obtained from all meteorology stations in and around the study area. Wind speed, humidity, and temperature data obtained from the meteorology stations were processed on the Arc GIS 10.5 software, and climate maps were created with an interpolation method using the Inverse Distance Weighted (IDW) command on this software.

IDW technique is an interpolation technique used to determine the cell values of unsampled points using the values of known sample points. The cell value is calculated by considering various points distancing from the relevant cell and subjecting the increase in the distance. The estimated values are a function of the distance and size of the neighboring points, and as the distance increases, the importance and effect on the cell to be estimated decreases. The formula used in the calculations is given below (Mueller et al. 2004; Taylan and Damçayırı 2016; Cetin et al. 2018).

$$
z\left(x_{O}\right)=\frac{\sum_{i=1}^{n} z\left(x_{i}\right) \cdot d_{i 0}^{-r}}{\sum_{i=1}^{n} d_{i 0}^{-r}}
$$

The location $\mathrm{X}_{0}$ for which the estimations are performed is a function of neighbor measurements $\left(\mathrm{z}\left(\mathrm{X}_{0 \mathrm{i}}\right)\right.$ and $i=1,2, \ldots, n)$; $r$ is the exponent determining the assigned range of each observation; and $d$ is the distance separating the observation location $X_{i}$ from the estimation location $X_{0}$. The larger the exponent, the smaller the assigned weight of observations that are distant from the estimation location. An increase in the exponent indicates that the estimations are very similar to the closest observations. The mathematical formulas are as described above; they were computed in the ArcGIS environment, which is a GIS software, and the maps were produced. This method has also been used in several previous studies (Setianto et al. 2013; Taylan \& Damçayırı 2016; Cetin et al. 2018; Qu et al. 2019; Golla et al. 2019).

Further, the climate maps obtained for the creation of biocomfort maps were reclassified using the Reclassify command in the Arc map 10.5 software. Comfortable areas were determined using the biocomfort index formula on the obtained classified climate maps. The index used by Cetin et al. (2020) was considered as a basis for the biocomfort index. According to this index, a region is considered comfortable if the temperature is $15^{\circ} \mathrm{C}-27^{\circ} \mathrm{C}$, relative humidity is $30-70 \%$, and wind speed is below 5 $\mathrm{m} / \mathrm{s}$ (Cetin 2020).

\subsubsection{General evaluation}

In the final stage of the study, a settlement area suitability map was created by overlapping the landslide, flood, and biocomfort maps. At this stage, the areas that are risky in terms of landslides or floods were specified as unsuitable areas for settlements. Areas with low landslide and flood risks but suitable for biocomfort were specified as fit for settlements, whereas areas with low landslide and flood risks but unsuitable for biocomfort were specified as areas where settlements could be established when necessary.

\section{Results}


The risk group maps created according to the landslide situation within the scope of the study is given in Fig. 5. When the landslide status of the study area is examined, approximately $99.03 \%$ of the study area is a landslide-free zone.

Only $0.23 \%$ of the total area is active landslide zone and $0.74 \%$ passive landslide zone. The risky areas in terms of landslides are in small groups, and they are concentrated in the northwest of the district. The map showing the flood susceptibility status of the study area is presented in Fig. 6.

In the study area, when the areas at the risk of flooding are examined, approximately $35.25 \%$ of the study area is of 1 st grade, $31.59 \%$ is of 2 nd grade, $22.32 \%$ is of 3 rd grade, $10.33 \%$ is of 4 th grade, and $0.51 \%$ of 5th grade lands. The flood risk is at a very low level in the 4th and 5th class lands, at a considerably high level in the 1 st and 2nd class lands, and at a medium level in the 3rd class lands. Areas with high or moderate flood risks are considered as unsuitable for construction, and areas that are suitable and unsuitable for construction in terms of flood risks are presented in Fig. 6.

As can be seen in Fig. 6, most of the study area is unsuitable for construction, and the flood risk in these areas is high or moderate. According to the performed calculations, approximately $66.84 \%$ of the study area is unsuitable for construction in terms of flood risks. The areas suitable and unsuitable for biocomfort in the study area are given in Fig. 7. In the biocomfort map, the suitable and unsuitable areas are assigned the pixel values of " 1 " and " 5 ," respectively.

As shown in the biocomfort suitability map of the study area, only a small part of the district, which is located in the northern side, is suitable for biocomfort; this area constitutes only $2.3 \%$ of the total study area. Approximately $97.7 \%$ of the study area is unsuitable in terms of biocomfort. The landslide susceptibility, flood susceptibility, and biocomfort suitability maps in raster format were collected using the map algebra function in the ArcGIS 10.5 software. On the obtained map, the index values vary between 3 and 15. The index value of this map was divided into three classes with equal intervals, and the settlement suitability map shown in Fig. 8 was obtained.

Owing to the risk of landslide or flooding in the study area, the areas unsuitable for establishing a settlement cover approximately $41.1 \%$ of the total study area. The areas with low flood and landslide risks but suitable for biocomfort constitute only $2.1 \%$ of the study area. In approximately $56.8 \%$ of the study area, the risk of landslides or floods is low, and these areas are unsuitable in terms of biocomfort. Therefore, these areas are secondarily preferred as settlement areas.

\section{Conclusion And Discussion}

The concentration of the population in urban centers throughout the world necessitates the introduction of new settlements areas in certain regions. However, the fact that natural disasters are not sufficiently considered when selecting new settlement areas causes thousands of people to die as a result of many disasters and causes enormous material damage. Landslides, one of the natural disasters in question, cause great damage and loss of lives every year around the world. 
When evaluated on a global scale, an area of 3.7 million $\mathrm{km}^{2}$ is exposed to landslides, and approximately 300 million people live in these areas. When examining at the Europe and Central Asia scales, the highest number of people exposed to landslides live in Turkey. In the last 50 years, 13,494 landslides have occurred in Turkey, and the total number of disaster victims affected by landslides has been recorded as 59,345 (Fidan 2019).

The main reason why landslides are extremely dangerous is that they can occur in a short period of time and cause many casualties. For example, on July 5, 1929, 148 people lost their lives as a result of the landslides that occurred around the districts of Of and Sürmene in Trabzon Province due to heavy rainfall that lasted for days (Fidan, 2019). Although landslides can occur in almost every region of Turkey, the Black Sea region is the most susceptible to landslides. The reason being that the Black Sea region has a mountainous topography, receives heavy rainfalls, and is close to the North Anatolian Fault Line (Yaman 2017; Kilicoglu et al. 2020).

Floods, which are among the natural disasters evaluated within the scope of this study, are disasters that can affect extensive areas and cause great material damage. Approximately 3 million people lost their lives in the flood events that occurred between 1900 and 2008 around the world, 2 billion people were affected, and cost of the material damage was approximately 200 billion USD. Approximately $49 \%$ of the 560 thousand people who lost their lives as a result of various natural disasters (e.g. floods, earthquakes, fires, storms, and volcanic eruptions) in the last 20 years is because of floods and overflows (Dölek 2013).

Floods and overflows, just like landslides, can cause a loss of numerous lives in a short period of time and result in great material damage. It has been reported that the hurricane Harvey and subsequent flooding in the USA damaged more than 204,000 buildings and caused approximately 125 billion USD in loss; the flood that occurred in Pakistan's eastern Hindu Kush region in 2010 killed approximately 1800 people and cost tens of billions of USD; and the floods that occurred in China in 2010 caused approximately 50 billion USD damage (Mukherjee and Singh 2019; Mahmood et al. 2019).

Floods and overflows are frequently seen in Turkey and can cause significant loss of life and material. In 695 flood events that took place in Turkey between 1975 and 2010, 634 people died, 810,000 hectares of land was submerged, and approximately 3.7 billion USD material damage occurred (Dölek 2013). Moreover, flood and overflow events will increase in the coming years in Turkey, which is among the countries that will be most affected by global climate change (Demirbaş and Aydın 2020; Cetin 2020).

Although landslides, floods, and overflows threaten the safety of the life and property of people, flood and overflow risks are not adequately evaluated during the selection of settlement areas; consequently, caused by the landslides, floods, and overflows, significant material damage and loss of life may happen. However, most of these losses can be prevented by conducting preliminary studies in the selection of suitable settlement areas. 
Another criterion to be considered in the selection of settlement areas is biocomfort. In short, biocomfort, which can be explained as the environmental conditions (temperature, wind speed, and humidity) in which people feel comfortable, is of great importance, especially in terms of energy consumption; moreover, it affects people's health, comfort, productivity, and psychology (Adiguzel et al. 2020; Cetin 2019; Gungor et al. 2021).

People use various heating and cooling devices to create appropriate biocomfort conditions in their environment; consequently, the amount of energy spent varies significantly depending on the biocomfort conditions. It is estimated that worldwide energy consumption will be approximately $60 \%$ higher in 2030 than it is today, and this increase will reach $100 \%$ in Turkey. In this energy consumption, the amount spent for heating and cooling has a significant proportion (Cetin et al. 2018; Zeren Cetin and Sevik 2020). Therefore, the establishment of settlement areas in places suitable for biocomfort is of great importance for energy efficiency as well as human health, comfort, happiness, productivity, and psychology (Potchter et al. 2018).

In the selection of settlement areas, identifying the safe areas considering natural disasters in the region first and then determining the suitable areas in terms of biocomfort is logical. However, the number of studies conducted by considering multicriteria in the selection of settlement areas is almost nonexistent. In the case studies conducted on this subject, Kilicoglu et al. (2020) identified the risk of floods and overflows from natural disasters, protected areas, high-voltage energy transmission lines, and suitable areas in terms of biocomfort in Bafra; according to these criteria, he stated that only $1.96 \%$ of the total study area is suitable to be used as settlement areas. In another study conducted in Atakum, in conclusion of calculations performed considering the landslide and flood risks, as well as the highvoltage energy transmission lines and biocomfort, it was calculated that only $15.11 \%$ of the study area is suitable to be used as a settlement area (Kilicoglu et al. 2021). In contrast, the present study stands out as it is one of the first studies in which priority ranking is considered in the selection of settlement areas according to multicriteria.

\section{Recommendations}

In addition to population growth throughout the world due to migration from rural to urban areas, population density is constantly increasing in certain regions, thereby necessitating the introduction of new settlements in these regions. However, in the selection of settlement areas, no sufficient preliminary examinations are performed; consequently, various natural disasters can cause significant life and property losses. In this study, the most suitable settlement areas were determined according to multicriteria in Canik District, which is one of the settlement areas where the population is constantly increasing.

Within the scope of the study, the risky areas in terms of landslides and floods, which are among the most likely natural disasters to occur in the region, were identified. Thereafter, suitable areas were determined in terms of biocomfort, which is highly important in terms of energy efficiency as well as 
human health, peace, and psychology, and the most suitable areas to be selected as settlements were determined. In the conclusion of the study, the areas that should not be established as settlements owing to the high level of landslide or flood risk in the region are identified. Moreover, the areas with low landslide and flood risks and also suitable for biocomfort, and therefore the most suitable to be selected as settlements, are determined. However, the most suitable areas for settlements constitute only $0.19 \%$ of the total study area, and these cannot meet the increasing settlement area demand. Therefore, it can be recommended to select areas that do not have the risk of landslides and floods but are unsuitable for biocomfort.

This study reveals that grading should be performed in the selection of settlement areas. While choosing a settlement area in any region, possible natural disasters in the region should be identified first, and these disasters should be ordered in terms of their threat potential. Moreover, biocomfort areas suitable to be selected as settlements should also be considered. In the next stages of the selection of settlement areas, criteria that affect the peace and comfort of people, such as distance to pollution sources, distance to noise sources, and proximity to natural areas, can also be evaluated. Thus, a priority order should be created for the selection of settlement areas using various other criteria.

Such studies can be conducted at very low costs before the settlement area selection, but in the following years, they can both minimize the loss of life and property in case of possible natural disasters and contribute to the fact that people can live in areas where they can be healthier and happier. However, unfortunately, the number of studies performed on this subject is very few, and the number of studies that are actually put into practice is almost nonexistent. Therefore, it is necessary to diversify and increase the studies on this subject, to execute on regional and local scales, and to ensure their implementation by sharing these studies with competent authorities.

\section{Declarations}

Ethics approval and consent to participate: Not applicable.

Consent for publication: Not applicable.

Availability of data and materials: The data that support the findings of this study are available from the corresponding author, Dr. Cem Kilicoglu, upon reasonable request.

Competing interests: The authors declare that they have no competing interests.

Funding: The authors declare that they have no funding resources.

Authors' contributions: Since the article is single-authored, the author has read and approved the final manuscript.

\section{References}


1. Adiguzel F, Cetin M, Kaya E, Simsek M, Gungor S, and Sert E. B (2020) Defining suitable areas for bioclimatic comfort for landscape planning and landscape management in Hatay, Turkey. Theor. Appl. Climatol. 139(3), 1493-1503. DOI:10.1007/s00704-019-03065-7

2. Akgun A, Sezer E. A, Nefeslioglu H. A, Gokceoglu C, and Pradhan B (2012) An easy-to-use MATLAB program (MamLand) for the assessment of landslide susceptibility using a Mamdani fuzzy algorithm. Comput Geosci. 38(1), 23-34. DOI: 10.1016/j.cageo.2011.04.012

3. Akıncı H, Doğan S,and Kılıçoğlu C (2011) Frekans oranı metodu kullanılarak Samsun il merkezinin heyelan duyarlılık haritasının üretilmesi. Harita Teknolojileri Elektronik Dergisi. 2(3), 13-27.

4. Akıncı H, Doğan S, and Kılıçoğlu C (2017) Landslide Susceptibility Maps of Canik (Samsun) Dıstrıct Usıng Bayesıan Probabılıty Model And Frequency Ratıo Method. Selçuk Üniversitesi Mühendislik, Bilim Ve Teknoloji Dergisi, 5(3), 283-299. https://dergipark.org.tr/tr/pub/sujest/issue/33943/373221

5. Akinci $\mathrm{H}$, Kilicoglu C, and Dogan S (2020) Random forest-based landslide susceptibility mapping in coastal regions of Artvin, Turkey. ISPRS Int. J. Geo-Inf. 9(9), 553.

https://doi.org/10.3390/ijgi9090553

6. Aricak B, Cetin M, Erdem R, Sevik H, and Cometen H (2019)The change of some heavy metal concentrations in Scotch pine (Pinus sylvestris) depending on traffic density, organelle and washing. Appl Ecol Environ Res .17 (3), 6723-6734. DOI:10.15666/aeer/1703_67236734

7. Aricak B, Cetin M, Erdem R,Sevik H, and Cometen H (2020) The usability of Scotch pine (Pinus sylvestris) as a biomonitor for traffic-originated heavy metal concentrations in Turkey. Pol. J. Environ. Stud.29 (2): 1051-1057 DOI: https://doi.org/10.15244/pjoes/109244

8. Bapalu G. V, and Sinha R(2005) GIS in flood hazard mapping: A case study of Kosi River Basin, India. GIS Development Weekly, 1(13), 1-3. https://doi.org/10.1007/s12524-008-0034-y

9. Breiman L (2001) Random Forests. Mach. Learn. 2001, 45, 5-32. https://doi.org/10.1023/A:1010933404324

10. Cesur A, Cetin I. Z, Aisha A. E. S. A, Alrabiti O. B. M, Aljama A. M. O, Jawed A. A, Cetin M, Sevik H, and Ozel H. B (2021) The usability of Cupressus arizonica annual rings in monitoring the changes in heavy metal concentration in air. ENVIRON SCI POLLUT R1-7. DOI: 10.1007/s11356-021-13166-4

11. Cetin M, Adiguzel F, Kaya O, Sahap A (2018) Mapping of bioclimatic comfort for potential planning using GIS in Aydin. Environ. Dev. Sustain. 20(1): 361-375. DOI: 10.1007/s10668-016-9885-5

12. Cetin M (2019) The effect of urban planning on urban formations determining bioclimatic comfort area's effect using satellitia imagines on air quality: a case study of Bursa city. AIR QUAL ATMOS HLTH 12(10), 1237-1249. DOI:10.1007/s11869-019-00742-4

13. Cetin M (2020) Climate comfort depending on different altitudes and land use in the urban areas in Kahramanmaras City. AIR QUAL ATMOS HLTH13(8), 991-999. DOI:10.1007/s11869-020-00858-y

14. Cetin $\mathrm{M}$, SevikH, and Cobanoglu $\mathrm{O}(2020) \mathrm{Ca}, \mathrm{Cu}$, and $\mathrm{Li}$ in washed and unwashed specimens of needles, bark, and branches of the blue spruce (Picea pungens) in the city of Ankara. ENVIRON SCI POLLUT R27(17), 21816-21825. DOI: 10.1007/s11356-020-08687-3 
15. Chen W, and Li Y (2020) GIS-based evaluation of landslide susceptibility using hybrid computational intelligence models. Catena, 195, 104777. DOI:10.1016/j.catena.2020.104777

16. Demirbaş M, and AYDIN R (2020) The Biggest Threat of The 21st Century: Global Climate Change. Ecol Life Sci.15(4), 163-179. https://doi.org/10.1111/j.1365-2486.2010.02393.x

17. Ding Q, Chen W, and Hong H (2017) Application of frequency ratio, weights of evidence and evidential belief function models in landslide susceptibility mapping. Geocarto Int. 32(6), 619-639. https://doi.org/10.1080/10106049.2016.1165294

18. Dölek i (2013) Muş'ta Yaşanan Sel ve Taşkınlara Neden Olan Doğal Faktörlerin Analizi. Marmara Coğrafya Dergisi, (28), 408-422.https://dergipark.org.tr/tr/pub/marucog/issue/475/3939

19. Erener A, and Düzgün H. S. B (2010) Improvement of statistical landslide susceptibility mapping by using spatial and global regression methods in the case of More and Romsdal (Norway). Landslides, 7(1), 55-68. https://doi.org/10.1007/s10346-009-0188-x

20. Fidan S (2019) Türkiye'deki ölüme sebep olan heyelanların coğrafı bilgi sistemleri (CBS) ile değerlendirilmesi, Yüksek Lisans Tezi, İstanbul Üniversitesi Sosyal Bilimler Enstitüsü Coğrafya Anabilim Dal http://nek.istanbul.edu.tr:4444/ekos/TEZ/ET000009.pdf

21. Gigović L, Pamučar D, Bajić Z, and Drobnjak S (2017) Application of GIS-interval rough AHP methodology for flood hazard mapping in urban areas. Water, 9(6), 360. https://doi.org/10.3390/w9060360

22. Golla V, Arveti N, Etikala B, Sreedhar Y, Narasimhlu K, and Harish P (2019) Data sets on spatial analysis of hydro geochemistry of Gudur area, SPSR Nellore district by using inverse distance weighted method in Arc GIS 10.1. Data Brief22, 1003-1011. doi: 10.1016/j.dib.2019.01.030

23. Gungor $S$, Cetin $M$, and Adiguzel $F$ (2021) Calculation of comfortable thermal conditions for Mersin urban city planning in Turkey. Air Qual Atmos Health. 14(4), 515-522. DOI:10.1007/s11869-02000955-y

24. Hong H, Miao Y, Liu J, and Zhu A. X (2019) Exploring the effects of the design and quantity of absence data on the performance of random forest-based landslide susceptibility mapping. Catena, 176, 45-64. DOI : 10.1016/j.catena.2018.12.035

25. Janbu N. E, Nemec W, Kirman E, and Özaksoy V (2009) Facies anatomy of a sand-rich channelized turbiditic system: the Eocene Kusuri Formation in the Sinop Basin, north-central Turkey. Sedimentary Processes, Environments and Basins: A Tribute to Peter Friend, 22, 457.

DOI:10.1002/9781444304411.ch19

26. Keskin I (2011) 1:100.000 Scale Geological Map of Turkey, No: 149 Samsun-E 36 and F36 Map Sheet; General Directorate of Mineral Research and Exploration, Geological Research Department: Ankara, Turkey. (In Turkish)

27. Kilicoglu C, Cetin M, Aricak B, and Sevik H (2020) Site selection by using the multi-criteria techniquea case study of Bafra, Turkey. Environ. Monit. Assess. 192(9), 1-12. DOI:10.1007/s10661-020-085621 
28. Kilicoglu C, Cetin M, Aricak B, Sevik H (2021) Integrating multicriteria decision-making analysis for a GIS-based settlement area in the district of Atakum, Samsun, Turkey. Theor Appl Climatol. 143,379388. https://doi.org/10.1007/s00704-020-03439-2

29. Kim J. C, Lee S, Jung H. S, and Lee S (2018) Landslide susceptibility mapping using random forest and boosted tree models in Pyeong-Chang, Korea. Geocarto Int. 33(9), 1000-1015. https://doi.org/10.1080/10106049.2017.1323964

30. Kuhn M (2008) Building predictive models in R using the caret package. J. Stat. Softw. 2008, 28, DOI: $10.18637 /$ jss.v028.i05

31. Kurtuluş C, Yeken T, and Durdağ D (2019) Estimating the Soil Water Content Using Electrical Conductivity, Oven Method and Speedy Moisture Tester. Eurasian Soil Sci. 52(12), 1577-1582. DOI:10.1134/S1064229319120081

32. Lee M. J, Kang J. E, and Jeon S (2012, July) Application of frequency ratio model and validation for predictive flooded area susceptibility mapping using GIS. In 2012 IEEE Int. Geosci. Remote Sens. Symp. (IGARSS) (pp. 895-898). IEEE. https://doi.org/10.1109/IGARSS.2012.6351414

33. Lee $S$ (2005) Application of logistic regression model and its validation for landslide susceptibility mapping using GIS and remote sensing data. Int. J. Remote Sens.26(7), 1477-1491. https://doi.org/10.1080/01431160412331331012

34. Lee S, Choi J, and MinK (2002) Landslide susceptibility analysis and verification using the Bayesian probability model. Environ. Geol 43(1-2), 120-131. https://doi.org/10.1007/s00254-002-0616-x

35. Moradi M, and Görer Tamer N (2017) Bursa Örneğinde Kentsel Büyümenin Yerel İklim Değişikliği Üzerine Etkisi. Planlama Dergisi, 27(1), 26-37. DOI: 10.14744/planlama.2017.38039

36. Mueller T. G, Pusuluri N. B, Mathias K. K, Cornelius P. L, Barnhisel R. I, and Shearer S. A (2004) Map quality for ordinary kriging and inverse distance weighted interpolation. SOIL SCI SOC AM J 68(6), 2042-2047. https://doi.org/10.2136/sssaj2004.2042

37. Mahmood S, Rahman A. U, and Shaw R (2019) Spatial appraisal of flood risk assessment and evaluation using integrated hydro-probabilistic approach in Panjkora River Basin, Pakistan. Environ. Monit. Assess.191(9), 573. DOI: 10.1007/s10661-019-7746-z

38. Mukherjee F, and Singh D (2019) Detecting flood prone areas in Harris County: A GIS based analysis. GeoJournal, 1-17. https://doi.org/10.1007/s10708-019-09984-2

39. Nhu V. H, Shirzadi A, Shahabi H, Chen W, Clague J. J, Geertsema M, and Pham B. T (2020) Shallow Landslide Susceptibility Mapping by Random Forest Base Classifier and its Ensembles in a SemiArid Region of Iran. Forests, 11(4), 421. https://doi.org/10.3390/f11040421

40. Ozel H. B, Cetin M, Sevik H, Varol T, Isik B, and Yaman B (2021) The effects of base station as an electromagnetic radiation source on flower and cone yield and germination percentage in Pinus brutia Ten. Biologia Futura, 1-7. DOI: 10.1007/s42977-021-00085-1

41. Ozer C. K (2014) Calcareous nannofossil assemblage changes and stable isotope data from Maastrichtian to Selandian in the Akveren Formation, Western Black Sea, Turkey. ARAB J GEOSCI 7(3), 1233-1247. DOI:10.1007/s12517-013-0856-y 
42. Potchter O, Cohen P, Lin T. P, and Matzarakis A (2018) Outdoor human thermal perception in various climates: A comprehensive review of approaches, methods and quantification. Sci. Total Environ. 631, 390-406. doi: 10.1016/j.scitotenv.2018.02.276.

43. Pourghasemi H.R, Pradhan B, Gokceoglu C, Moezzi K.D. A comparative assessment of prediction capabilities of Dempster-Shafer and Weights-of-evidence models in landslide susceptibility mapping using GIS. Geomat. Nat. Hazards Risk 2013, 4, 93-118 https://doi.org/10.1080/19475705.2012.662915

44. Qu R, Xiao K, Hu J, Liang S, Hou H, Liu B, and Yang J (2019) Predicting the hormesis and toxicological interaction of mixtures by an improved inverse distance weighted interpolation. Environ. Int.130, 104892. https://doi.org/10.1016/j.envint.2019.06.002

45. Rahmati O, Pourghasemi H. R, and Zeinivand $H$ (2016) Flood susceptibility mapping using frequency ratio and weights-of-evidence models in the Golastan Province, Iran. Geocarto Int. 31(1), 42-70. https://doi.org/10.1080/10106049.2015.1041559

46. Samanta S, Pal D. K, and Palsamanta B (2018) Flood susceptibility analysis through remote sensing, GIS and frequency ratio model. Appl. Water Sci. 8(2), 66. https://doi.org/10.1007/s13201-018-0710-1

47. Setianto A, Setianto A, Triandini T, and Triandini T (2013) Comparison of kriging and inverse distance weighted (IDW) interpolation methods in lineament extraction and analysisJ. Southeast Asian Appl. Geology. 5(1), 21-29. https://doi.org/10.22146/jag.7204

48. Sevik H, Cetin M, Ozel H. U, Ozel H. B, Mossi M. M. M, and Cetin I. Z (2020) Determination of Pb and $\mathrm{Mg}$ accumulation in some of the landscape plants in shrub forms ENVIRON SCI POLLUT R 27(2), 2423-2431. https://dergipark.org.tr/tr/download/article-file/1621350

49. Skilodimou H. D, Bathrellos G. D, Chousianitis K, Youssef A. M, and Pradhan B (2019)Multi-hazard assessment modeling via multi-criteria analysis and GIS: a case study. Environ. Earth Sci.78(2), 47. https://doi.org/10.1007/s12665-018-8003-4

50. Souissi D, Zouhri L, Hammami S, Msaddek M. H, Zghibi A, and Dlala M (2020) GIS-based MCDMAHP modeling for flood susceptibility mapping of arid areas, southeastern Tunisia. Geocarto Int.35(9), 991-1017. https://doi.org/10.1080/10106049.2019.1566405

51. Şen G, Güngör E, and Şevik H (2018) Defining the effects of urban expansion on land use/cover change: a case study in Kastamonu, Turkey. Environ. Monit. Assess.190 (8), 454.

DOI:10.1007/s10661-018-6831-z

52. Şevik H Change of Cu Concentration in Some Edible Landscape Plants Grown in Ankara City Center. Kastamonu Üniversitesi Mühendislik ve Fen Bilimleri Dergisi, 6(1), 1-7. https://dergipark.org.tr/tr/pub/kastamonujes/issue/55221/719735

53. Taalab K, Cheng T, and Zhang Y (2018) Mapping landslide susceptibility and types using Random Forest. Big Earth Data, 2(2), 159-178. https://doi.org/10.1080/20964471.2018.1472392

54. Taylan E.D, and Damçayırı D (2016) Isparta Bölgesi Yağış değerlerinin IDW ve Kriging enterpolasyon yöntemleri ile tahmini. Teknik Dergi, 27(3), 7551-7559.

https://dergipark.org.tr/tr/pub/tekderg/issue/28139/299030 
55. TUIK, 2020: https://www.tuik.gov.tr/

56. Turkyilmaz A, Cetin M, Sevik H, Isinkaralar K, and Saleh E. A. A (2020) Variation of heavy metal accumulation in certain landscaping plants due to traffic density. Environ. Dev. Sustain.22 (3), 23852398 https://doi.org/10.1007/s10668-018-0296-7

57. Vakhshoori V,Pourghasemi H. R, Zare M, and Blaschke T (2019) Landslide susceptibility mapping using GIS-based data mining algorithms. Water, 11(11), 2292. https://doi.org/10.3390/w11112292

58. Varol T, Canturk U,Cetin M,Ozel H. B,and Sevik H (2021) Impacts of climate change scenarios on European ash tree (Fraxinus excelsior L.) in Turkey. FOREST ECOL MANAG, 491, 119199. DOI: 10.1016/j.foreco.2021.119199

59. Wang Q, Guo Y, Li W, He J, and Wu Z (2019a) Predictive modeling of landslide hazards in Wen County, northwestern China based on information value, weights-of-evidence, and certainty factor. Geomatics, Nat. Hazards Risk .10(1), 820-835. https://doi.org/10.1080/19475705.2018.1549111

60. Wang Y, Hong H, Chen W,Li S, Pamučar D, GigovićL,and Duan H (2019b) A hybrid GIS multi-criteria decision-making method for flood susceptibility mapping at Shangyou, China. Remote Sens. 11(1), 62.

61. Worldometers, 2020. https://www.worldometers.info/

62. Yaman B (2017) Root wood anatomy of a black pine tree: landslide traces. Kastamonu Üniversitesi Orman Fakültesi Dergisi, 17(1), 1-8. http://dergipark.gov.tr/.../295309

63. Yanar T, Kocaman S, andGokceoglu C (2020) Use of Mamdani Fuzzy Algorithm for Multi-Hazard Susceptibility Assessment in a Developing Urban Settlement (Mamak, Ankara, Turkey). ISPRS Int. J. Geoinf 9(2), 114. https://doi.org/10.3390/ijgi9020114

64. Yin J, Ye M, Yin Z, and Xu S (2015) A review of advances in urban flood risk analysis over China. Stoch Environ Res Risk Assess .29(3), 1063-1070. DOI:10.1007/s11069-016-2444-4

65. Youssef A. M, Pourghasemi H. R, Pourtaghi Z. S, and Al-Katheeri M. M (2016) Landslide susceptibility mapping using random forest, boosted regression tree, classification and regression tree, and general linear models and comparison of their performance at Wadi Tayyah Basin, Asir Region, Saudi Arabia. Landslides, 13(5), 839-856. https://doi.org/10.1007/s10346-015-0667-1

66. Zeren Cetin I,and Sevik H (2020) Investigation of the relationship between bioclimatic comfort and land use by using GIS and RS techniques in Trabzon. Environ. Monit. Assess.192(2), 71. DOI: 10.1007/s10661-019-8029-4

\section{Figures}



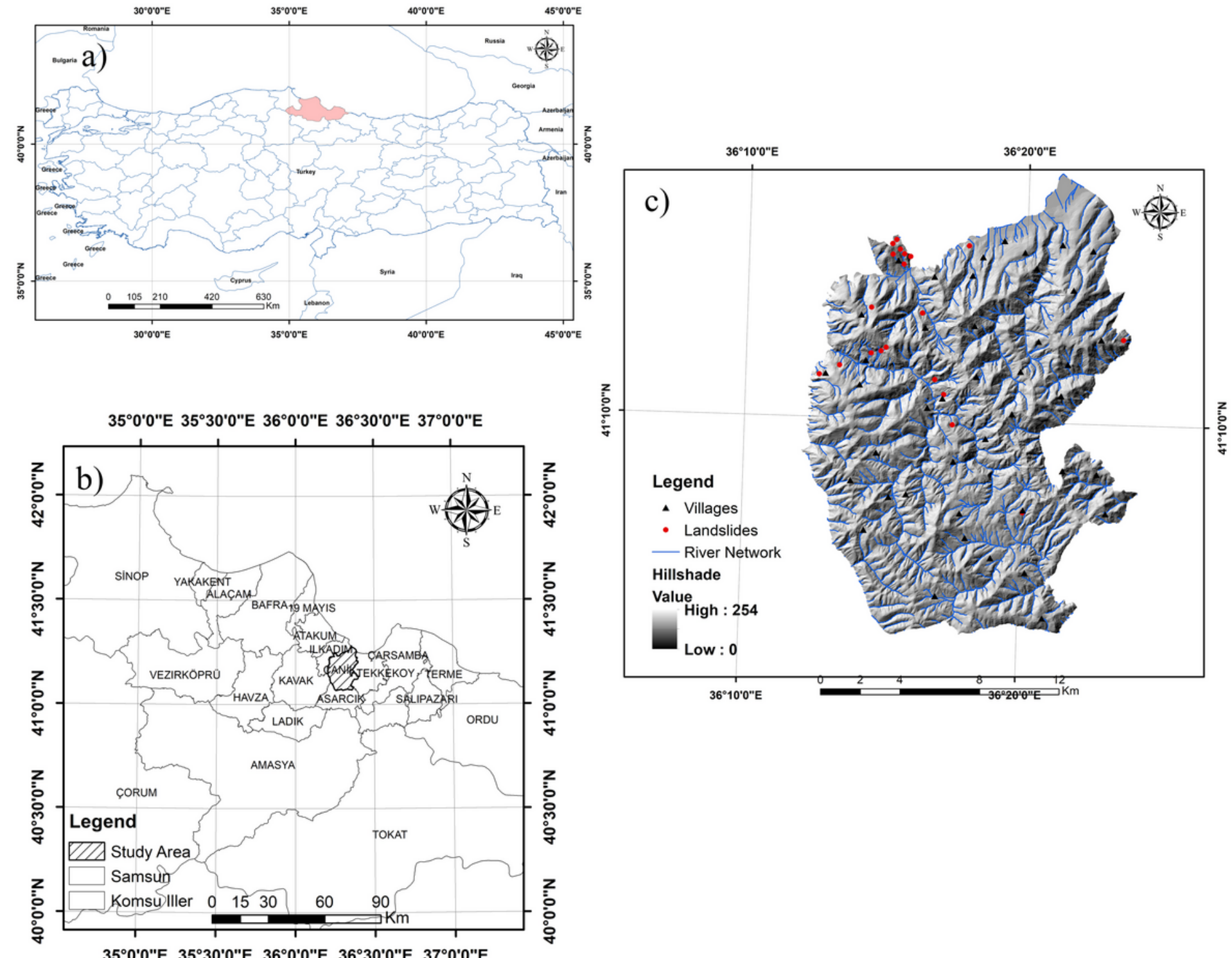

\section{Figure 1}

Study area maps. (a) Location map of the study area in Turkey; (b) location map of the Canik (Samsun) region; (c) location map showing settlements and landslides in the study area 


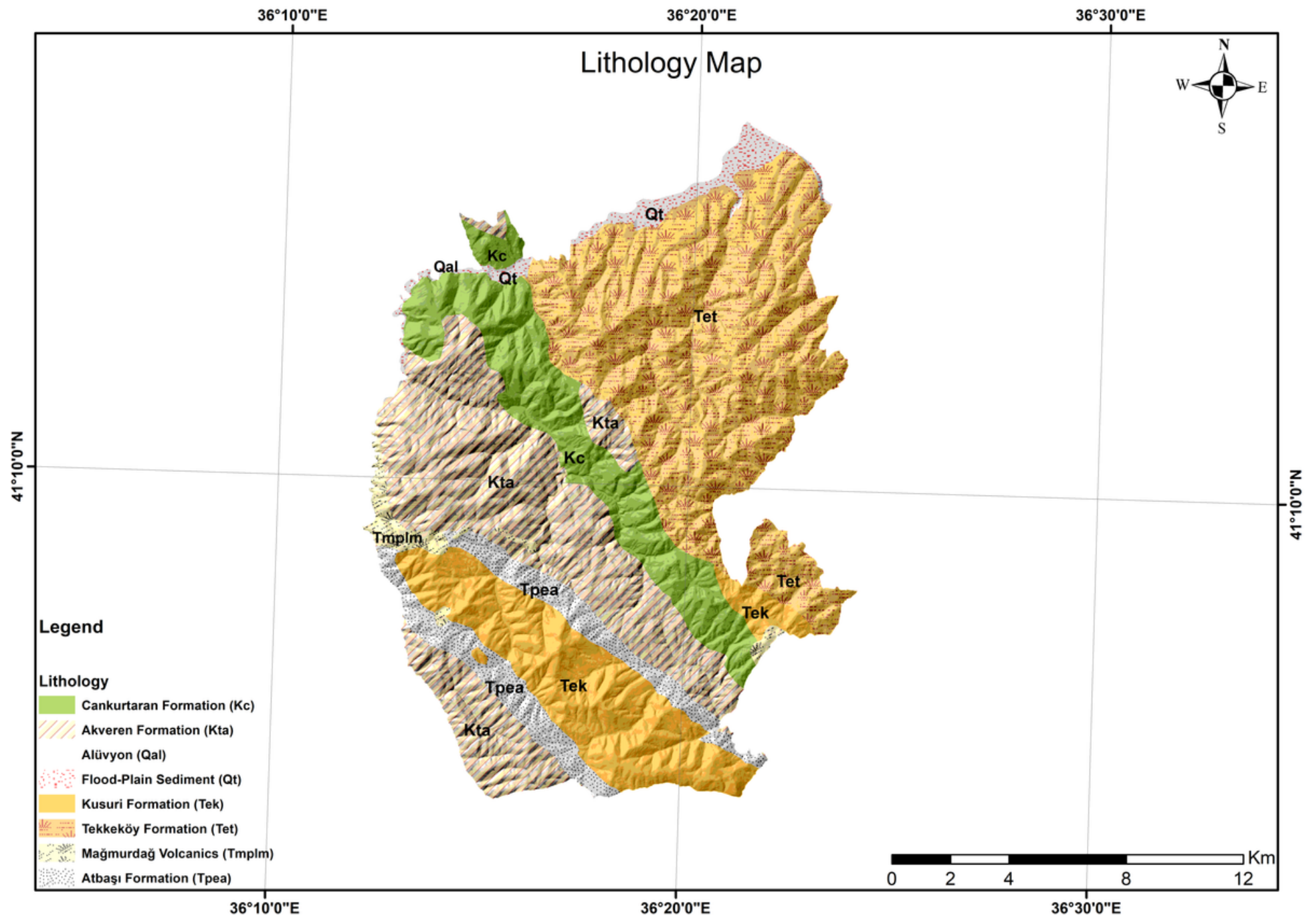

Figure 2

Geological map of the study area (Keskin 2011) 

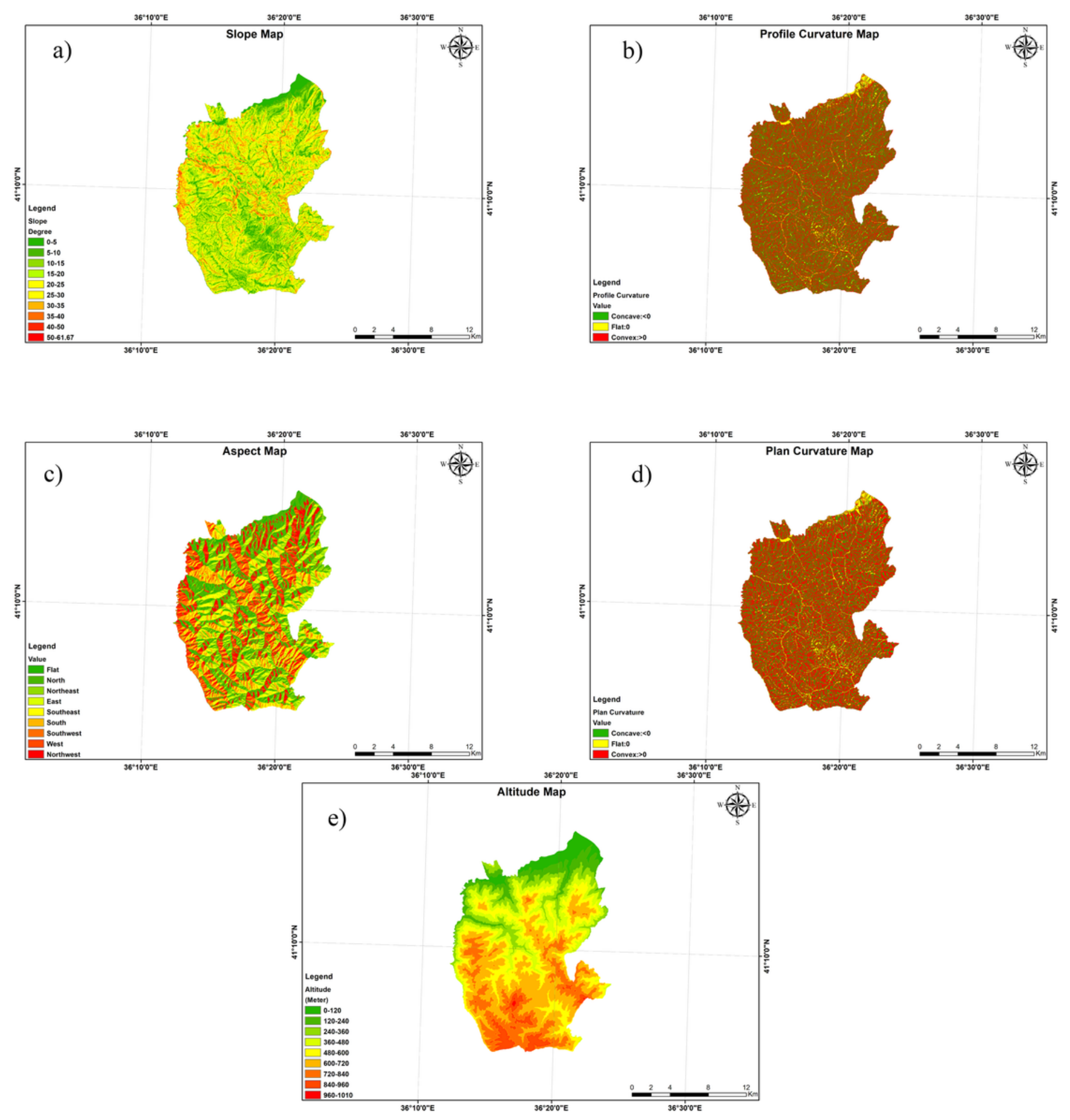

\section{Figure 3}

Topographic factor maps: (a) elevation, (b) aspect, (c) plan curvature, (d) profile curvature, and (e) slope 

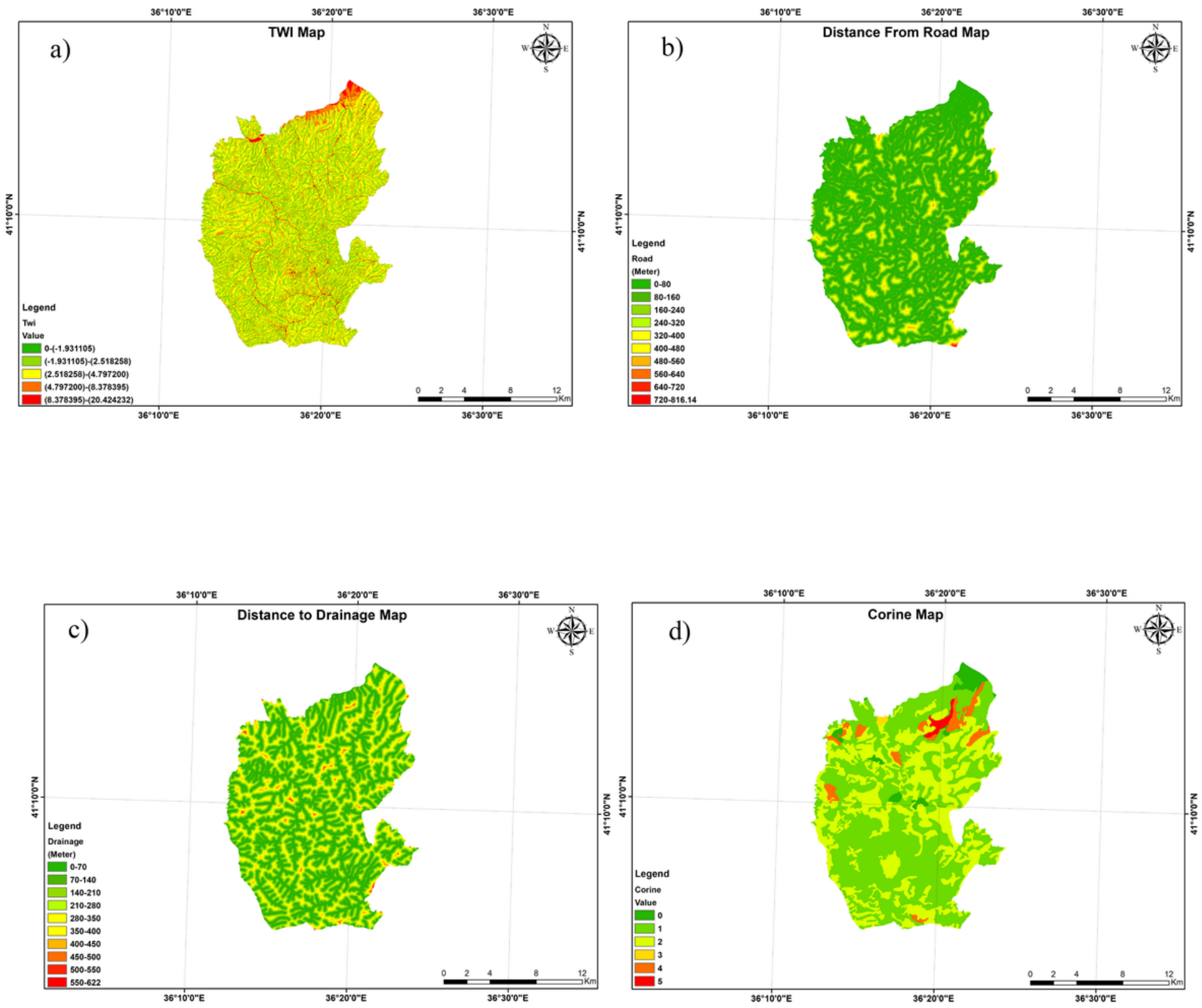

\section{Figure 4}

Landslide-conditioning factor maps: (a) corine map, (b) distance to drainage map, (c) topographic wetness index, and (c) distance to roadmap 


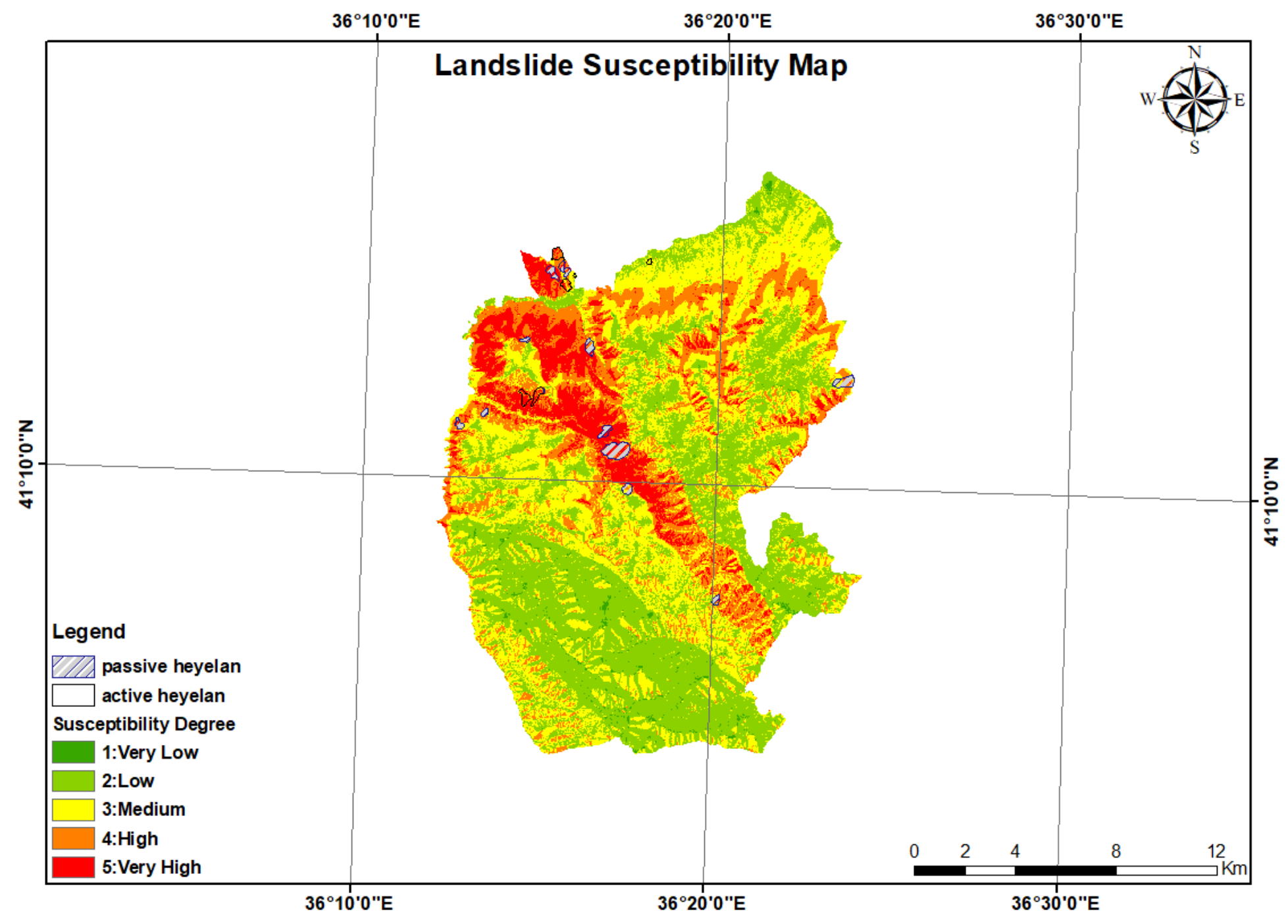

Figure 5

Landslide susceptibility maps produced using the RF model 


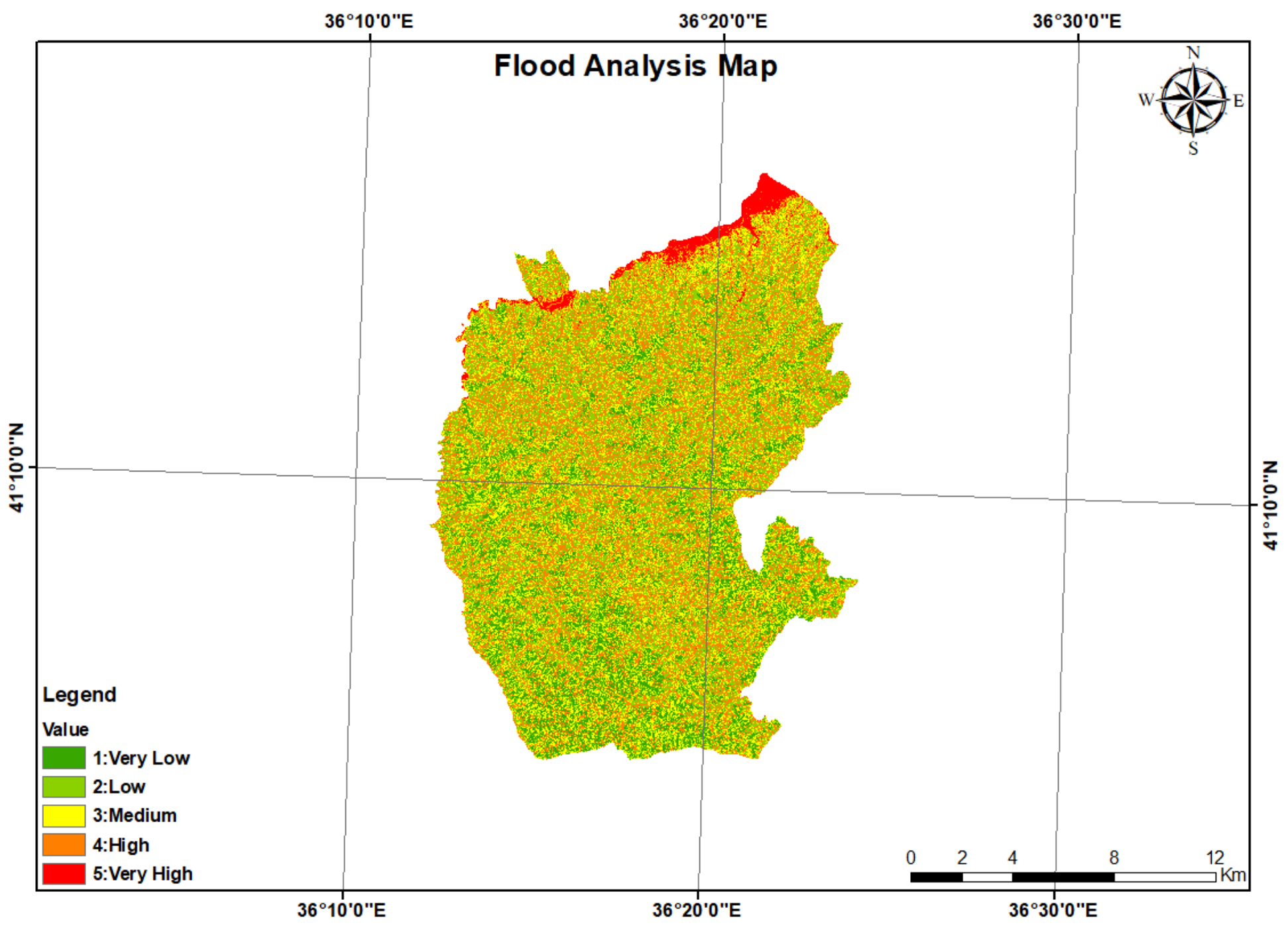

Figure 6

Flood susceptibility maps 


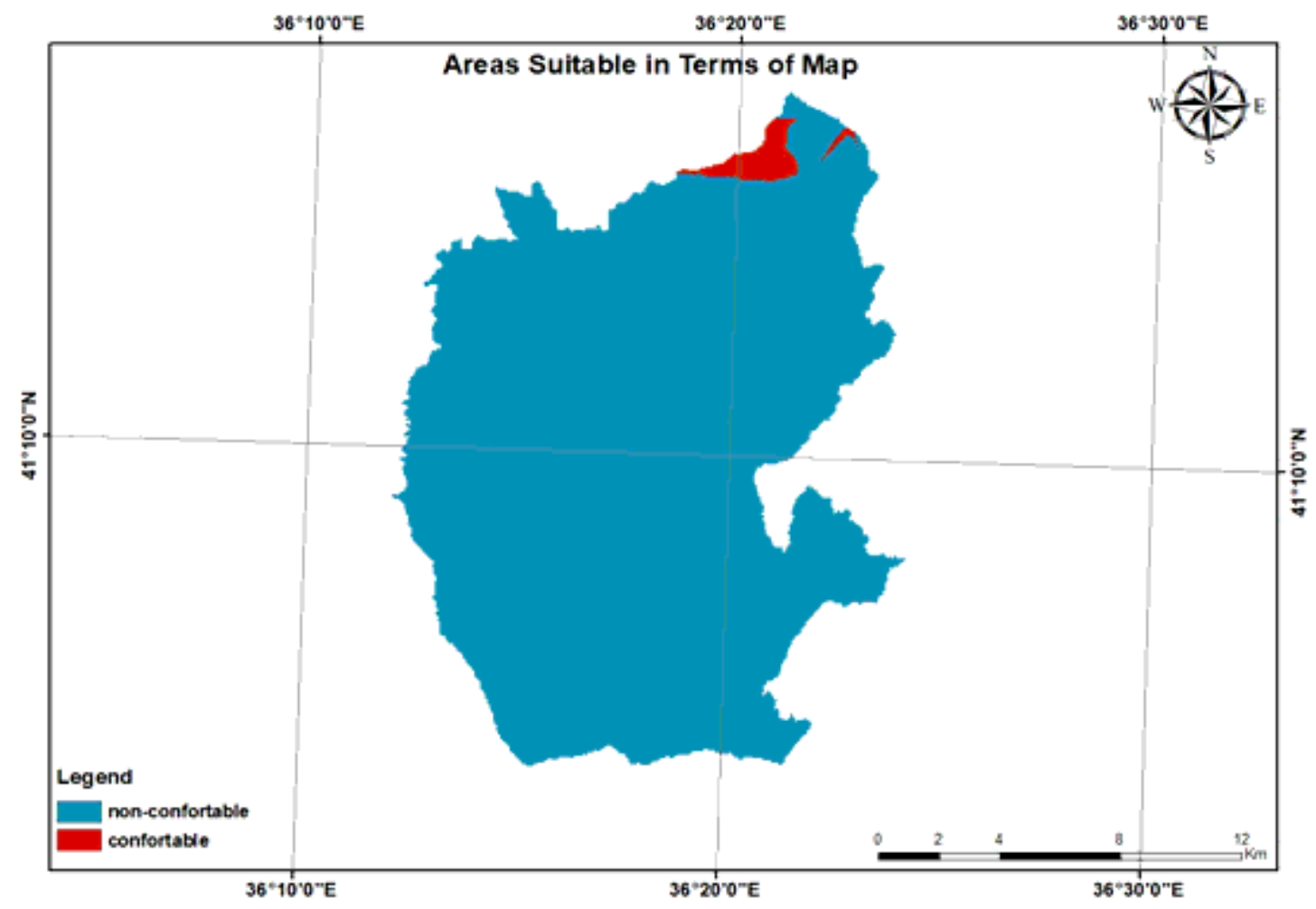

Figure 7

Areas suitable in terms of biocomfort in Canik

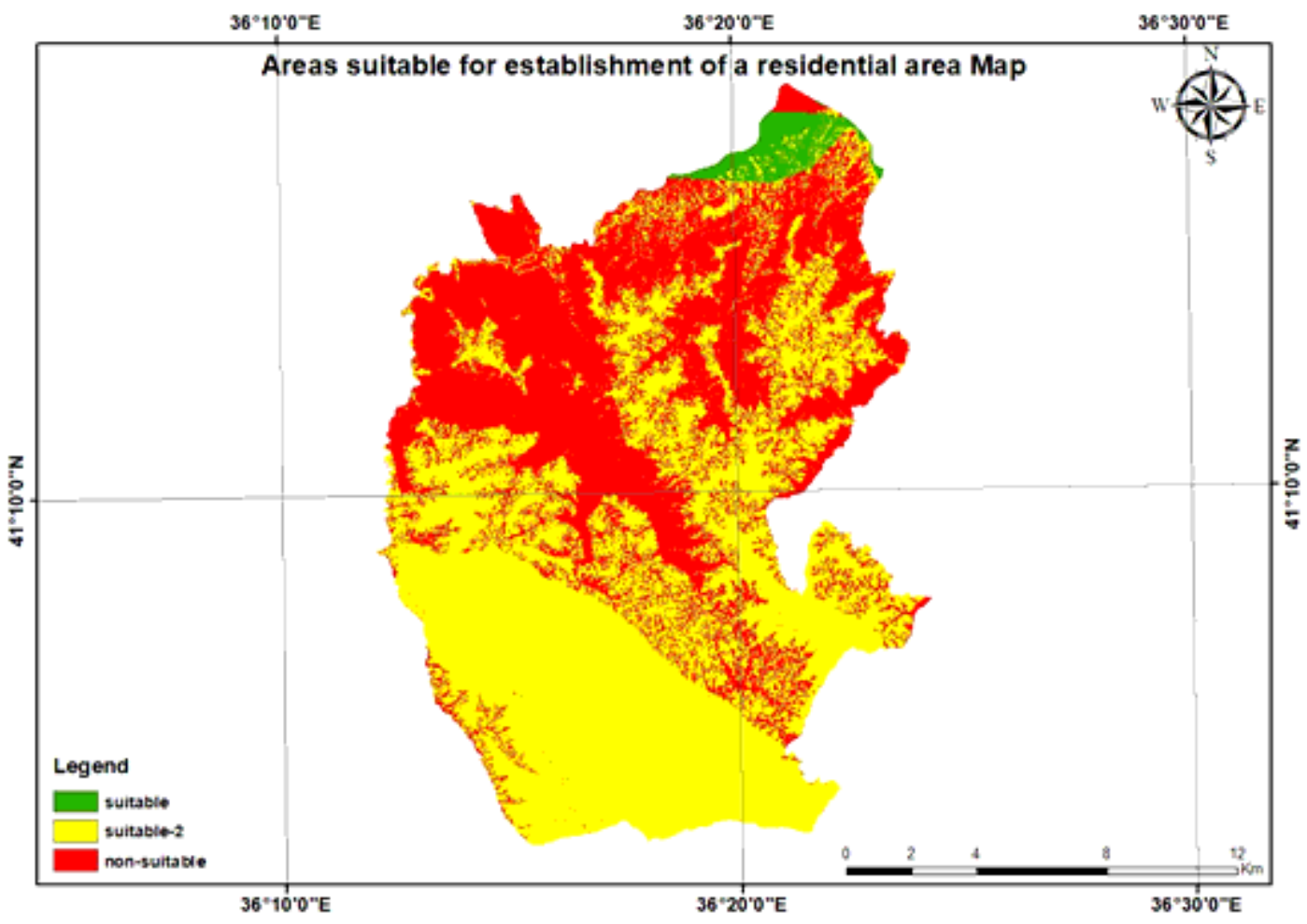

Figure 8

Areas suitable for the establishment of settlements in Canik 